\title{
NOTES ON THE ANATOMY, POSITIONING AND HOMOLOGY OF THE PELVIC BONES IN SMALL CETACEANS (CETACEA, DELPHINIDAE, PONTOPORIIDAE)
}

\author{
Paulo C. Simões-Lopes ${ }^{1, *}$ and Carolina S. Gutstein ${ }^{1}$
}

\begin{abstract}
This report analyzes the variations in positioning and orientation of the pelvic bones in small cetaceans, and contributes to establishing a possible homology based on the attachment of the abdominal musculature. Seven carcasses of three cetacean species (Tursiops truncatus, Sotalia guianensis ${ }^{1}$, Pontoporia blainvillei) were analyzed. There is some variation in positioning and orientation of the pelvic bones in these species. Two pairs of abdominal muscles (levator ani and ischiumcavernosus) presented a tendinous connection to the pelvic bones in the species mentioned above, and the dorsolateral crest, the ventromedial protuberance and the ischial tuberosity occur in all analyzed species, thus constituting homologous structures. One can confirm at least the presence of the ischium as a component of the innominate bone of the cetacean.

Resumo - Analisam-se as variações de posicionamento e orientação dos ossos pélvicos de pequenos cetáceos, contribuindo-se para estabelecer possível homologia baseada nas ligações com a musculatura abdominal. Foram analisadas sete carcaças de três espécies de cetáceos (Tursiops truncatus, Sotalia guianensis, Pontoporia blainvillei). Ocorre certa variação no posicionamento e orientação dos ossos pélvicos nessas espécies. Dois pares de músculos abdominais (levator ani and ischium-cavernosus) possuem ligações tendinosas com os ossos pélvicos nas espécies estudadas e a crista dorsolateral, a protuberância ventromedial e a tuberosidade isquiática ocorrem nas espécies analisadas, sendo portanto estruturas homólogas. Confirma-se ao menos a presença do ischium como um componente do osso inominado dos cetáceos.
\end{abstract}

Keywords: pelvic bone, innominate bone, homology, Tursiops truncatus, Sotalia guianensis, Pontoporia blainvillei.

\section{Introduction}

The progressive reduction of the pelvic girdle and the hindlimbs in primitive cetaceans is well represented by complete fossil series (e.g., Kellogg, 1928; Gingerich et al., 1994; Thewissen et al., 1994; O'Leary and Geisler, 1999; O'Leary and Uhen, 1999; Gingerich, 2001; Thewissen et al., 2001). On the other hand, the vestigial pelvic bones abdominal bones, ossa innominata - of modern adult cetaceans are still a matter of doubt and contradiction. There is no precise determination about the positioning and the anatomical orientation for these bones, and differing opinions have already been reported (Arvy, 1979). Likewise, there seems to be no agreement either on the number of bones involved or the exact bones to which such vestiges correspond. Arvy (1979) even claimed that there is no homology with the pelvic girdle of the remaining placental mammals, since the nerves are so greatly altered in that region and a connection to the vertebral column is lacking. Such an opinion finds no current support, although to establish the homology for these vestiges constitutes no trivial problem (Bejder and Hall, 2002).

For a number of adult mysticetes, an additional bone corresponding to the femur has been reported (Lönnberg, 1910; Omura, 1978; 1980), but among odontocetes only sperm whales exhibit cartilaginous vestiges of the femur (Deimer, 1977).

The development of external hindlimbs appears in initial embryos of Stenella attenuata Gray, 1846, but such rudiments regress after 48 days of gestation (Sedmera et al., 1997). Special cases of spontaneous atavism in which external appendices, even showing fingers, were reported for both adult humpback whales and sperm whales (Andrews, 1921; Kellogg, 1928).
The protocols and dissections are usually not aimed at the recovery of pelvic bones, and that becomes clear by the fact that they are rare in scientific collections and can be seen in the wrong position in skeletons assembled for exhibition in museums. Thus, this report analyzes the variations in positioning and orientation of such bones, and also contributes to establishing a possible homology based on the attachment of the abdominal musculature of the perineum.

\section{Material and Methods}

The location and orientation of the pelvic bones were determined by direct dissection in seven carcasses of three cetacean species recently stranded in southern Brazil, all deposited at the marine mammal collection of the "Departamento de Ecologia e Zoologia of the Universidade Federal de Santa Catarina" (UFSC): the bottlenose dolphin, Tursiops truncatus (Montagu, 1821) (UFSC 1281, 1285, 1295); the marine tucuxi or estuarine dolphin, Sotalia guianensis ( $\mathrm{P}$. J. van Bénéden, 1864) (UFSC 1289, 1297); and the franciscana, Pontoporia blainvillei (Gervais \& d'Orbigny, 1844) (UFSC $1288,1290)$. The dissection began with a longitudinal incision in the genital region, removing the tissue to the sides at the level of the last lumbar vertebrae (Figure 1). The position of each pelvic bone was determined in relation to the surface of the body (region of the perineum), to the axial skeleton, and to the parts of the genital apparatus (uterus or penis). The attachment of the tendons of the abdominal musculature and the presence/absence of cartilage were also noted.

Radiographs of fetuses of the estuarine dolphin (UFSC 1075, 1315) and of franciscana (UFSC 1021, 1294) were taken for the purpose of analyzing the centers of ossification. These

\footnotetext{
${ }^{1}$ Universidade Federal de Santa Catarina, Departamento de Ecologia e Zoologia, CCB, Laboratório de Mamíferos Aquáticos. P.O.Box 5102, Florianópolis, SC 88040-970 Brazil.

*Corresponding author: lamaqsl@ccb.ufsc.br.

${ }^{2}$ Although LAJAM has adopted Sotalia fluviatilis as the scientific name for the marine tucuxi, the authors, in accordance with Monteiro Filho et al. (2002), used S. guianensis - Monteiro Filho, E.L A., Monteiro, L.R. and Dos Reis, S.F. (2002). Skull shape and size divergence in dolphins of the genus Sotalia: a tridimensional morphometric analysis. Journal of Mammalogy 83:125-134.
} 
fetuses had been preserved in 5\% formaldehyde, except for UFSC 1294, which had been dissected and its skeleton subsequently archived.

The terminology used in this study generally follows that of Lessetisseur and Saban (1967); Lessetisseur (1968); Habel (1975) and Arvy (1979).

\section{Results}

The vestiges of the pelvic girdle were located in the hyposomatic musculature on each side of the genital region. Apparently, the variation in position was greater in females than in males. In males, the pelvic bones were located immediately posterior to the urogenital opening and anterior to the anus in these three cetacean species. In females, their position was variable. These bones were situated laterally to the mammary and urogenital openings. However, they may appear in a posterior location in some T. truncatus, or anterior in P. blainvillei. Such variability is partly due to the relative location of the two nipples, which also varies. In the three species, the pelvic bones were approximately at the same distance from the caudal notch, between $28 \%$ and $34.5 \%$ of the total length.

The orientation of these bones was not completely parallel to the axis of the body and was variable in the three species analyzed. In T. truncatus and S. guianensis, the anterior extremities of the pelvic bones were closer to each other, while in P. blainvillei the opposite was observed. In $T$. truncatus and P. blainvillei, the posterior extremities of these bones bent discretely to the ventral surface of the body, while in S. guianensis the opposite was observed. In $P$. blainvillei, the pelvic bones were situated about $20 \mathrm{~mm}$ from the ventral surface of the body. This distance was greater in T. truncatus and S. guianensis, and varied from 30 to 75 $\mathrm{mm}$ in both species, depending on the depth of the blubber. The position of the pelvic bones in relation to the region of the vertebral column was consistent, but variable among the species studied. In P. blainvillei, the anterior extremity of the pelvic bones reached the $2^{\text {nd }}$ caudal vertebra (Ca) and in T. truncatus and S. guianensis it was situated in a more posterior position, between the $3^{\text {rd }}$ and the $5^{\text {th }} \mathrm{Ca}$. It was not possible to establish a homology between the pelvic bones and the sacral region of the vertebral column.

The pelvic bones were situated below the hyposomatic locomotory musculature. In the region between the $2^{\text {nd }}$ and the $5^{\text {th }} \mathrm{Ca}$, three branches of locomotion muscles could be identified in a dorsal situation to the pelvic bones: hypaxialis lumborum pars dorso lateralis (more laterally), flexor caudae lateralis and flexor caudae medialis (both dorsomedial) (e.g. Lessetisseur, 1968: 652; Crovetto, 1991: 112). The three branches of locomotion muscles together are sometimes referred to in the literature simply as hypaxialis.

Two pairs of abdominal muscles situated in a more

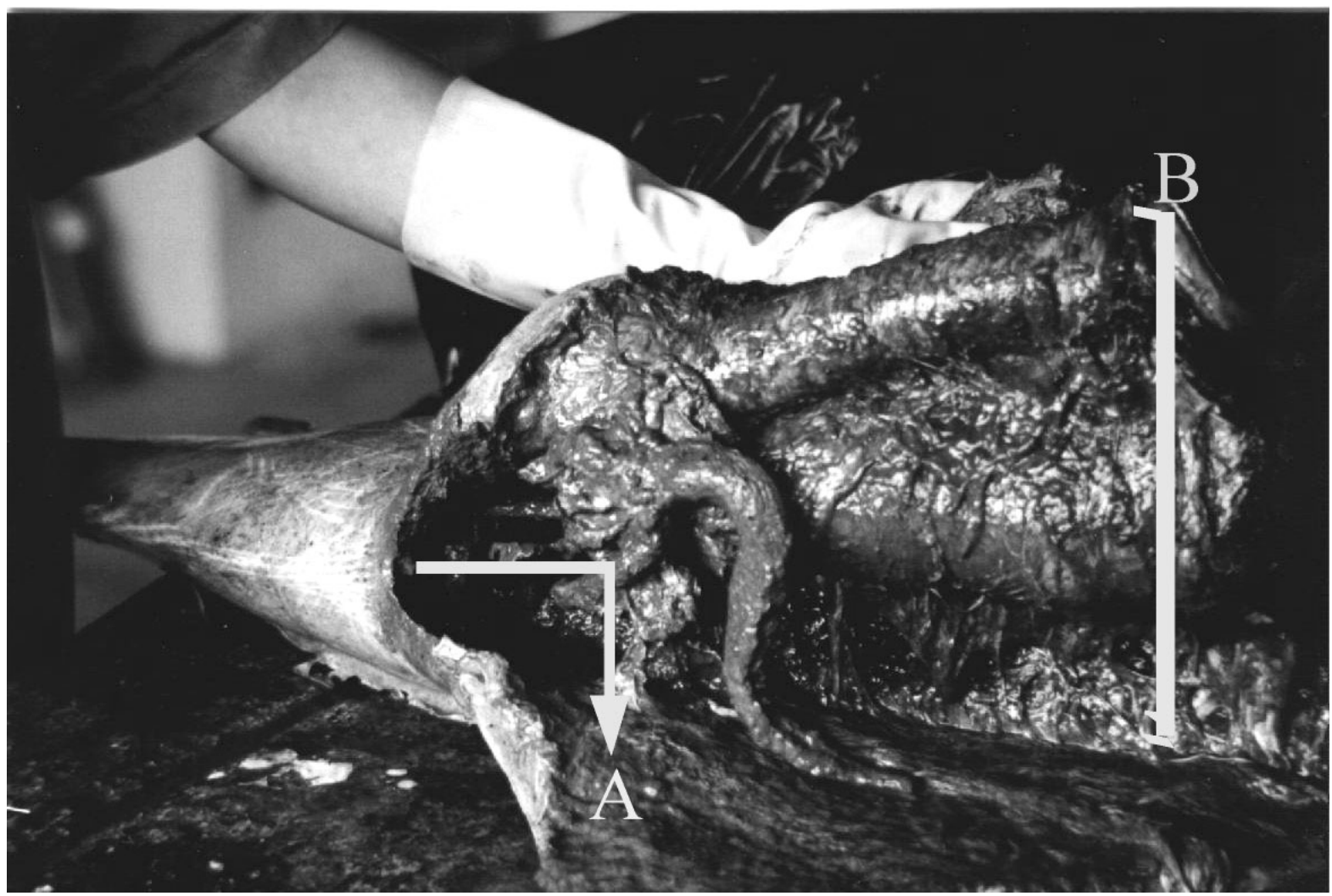

Figure 1. Dissection of a specimen (UFSC 1291) of estuarine dolphin (Sotalia guianensis) in advanced decomposition state, showing longitudinal (A) and transversal (B) cuts. Ventral view. 
medial position presented a tendinous connection to the pelvic bones in the species mentioned above: levator ani (= ischium-analis) and ischium-cavernosus (= erector penis) (Figures 2 and 3). Their origins and tendinous insertions were identified and considered in order to establish homologies with other mammals. The levator ani was situated ventromedially in relation to each pelvic bone, and in it secondary attachments in at least two points of the anterior portion of the bone were found: dorsolateral crest and ventromedial protuberance (respectively, "face dorsale" and "face antérieure" of Lessetisseur, 1968). This muscle originated at the first haemal arches (arcus hemalis) and was inserted to the anal sphincter, distally. The ischiumcavernosus originated in the caudal process of the pelvic bone, more specifically in the ventral thickening (or ischial tuberosity from Habel, 1975), and was inserted to the body of the penis.

The X-rays of fetuses of S. guianensis and P. blainvillei did not show any kind of precocious ossification of pelvic vestiges, but the dissection of the fetus of $P$. blainvillei (UFSC 1294) revealed a cartilaginous matrix $2 \mathrm{~mm}$ from the ventral surface of the body.

\section{Discussion}

Since there is no connection of the pelvic bones with the vertebral column in cetaceans, a certain variability in their positioning and orientation is expected. Arvy (1979) situates them as anterior to the anus in the space that corresponds to the perineum, and Rommel (1990) reports them as being dorsal to the anus. In the three species here analyzed, a certain variation of position occurred, with the pelvic bones situated both in the space of the perineum and at the sides of the urogenital opening, or even immediately anterior to it. In the case of spontaneous atavisms in humpback whales and sperm whales, the external limbs are situated at each side of the genital slit (Andrews, 1921; Kellogg, 1928). Pelvic bones situated at each side of the genital slit can be verified in the atlas by Kastelein et al. (1997: 138139), which portrays a female harbor porpoise, Phocoena phocoena (Linnaeus, 1758). Their spatial orientation is presented as parallel to the axis of the body both in assembled skeletons in museums and in the literature in general (see Howell, 1930: 303; Bejder and Hall, 2002: fig. 3E). Only Arvy (1979) mentions that the posterior extremities of these bones are closer to each other in Orcinus orca (Linnaeus, 1758). In none of the analyzed species in this study was the orientation of the pelvic bones parallel. The specimens of franciscana agree with what was observed by Arvy (1979), but the bottlenose dolphin and the estuarine dolphin showed an opposite trend. The small sample at issue does not allow wider generalization, but it is possible that there is both an inter-specific and an individual variation.

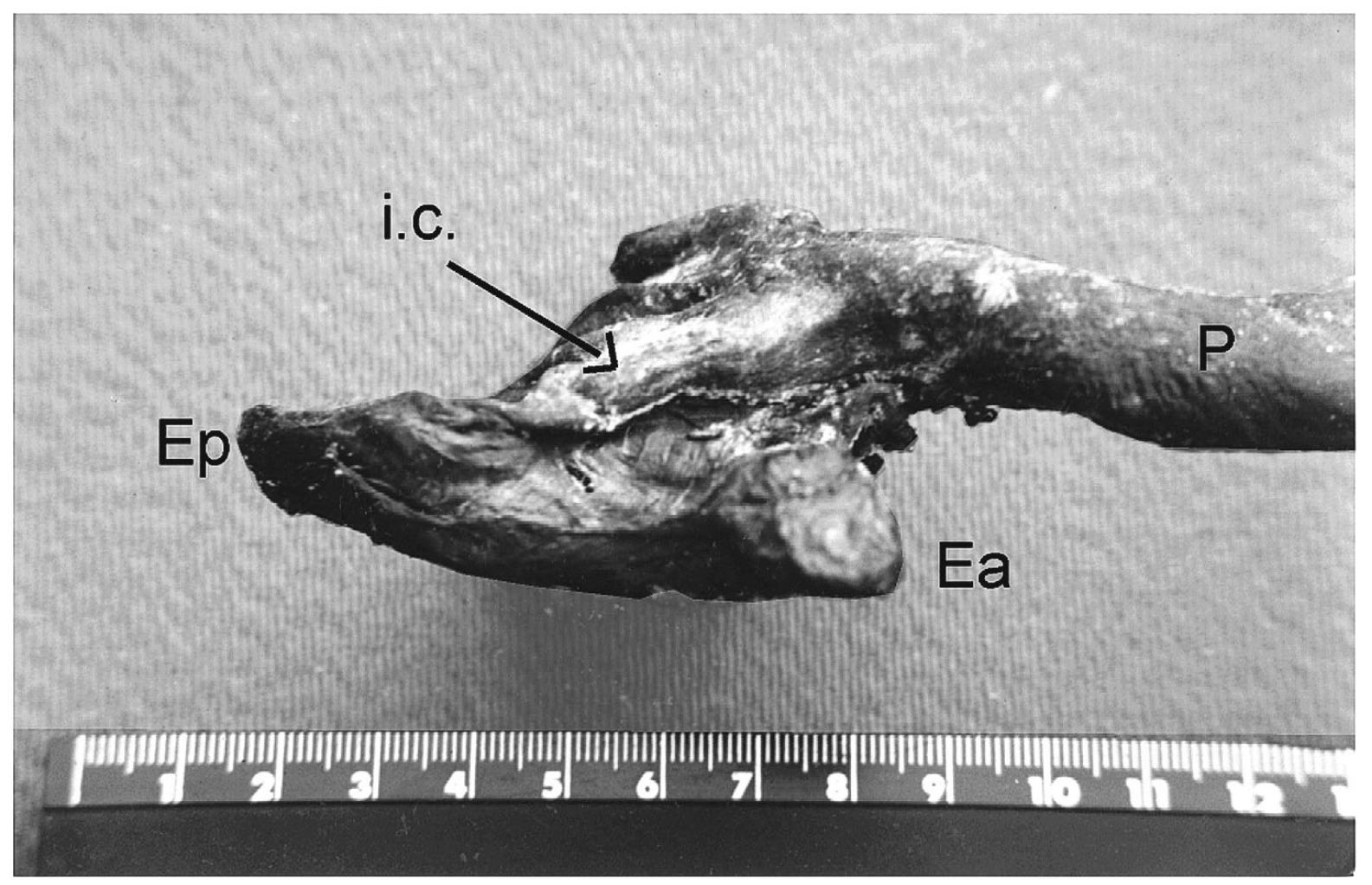

Figure 2. Situation of the pelvic bone of the estuarine dolphin (Sotalia guianensis) (UFSC 1291, lateral view); the arrow indicates the origin of the ischium-cavernosus muscle at the ischial tuberosity in the caudal process. (Ea) anterior extremity and (Ep) posterior extremity of the right pelvic bone; (P) body of the penis; (i.c) ischium-cavernosus. 
The position of the pelvic bones in the region of the first caudal vertebrae is similar to that reported in the literature (reproduction of the drawings by Alpers, Dubar, Flower and Eschricht after Arvy, 1979; Kastelein et al., 1997), but Bejder and Hall (2002) situate them anteriorly to the first haemal arches, or chevrons.

The difficulty in establishing the homology of the pelvic vestiges of cetaceans is due not only to the absence of a connection to the vertebral column, but also to the loss of their locomotion functions. However, the musculature of the perineum is present and is associated with the pelvic vestiges (Howell, 1930: 303; Lessetisseur, 1968: 692), participating in defecation, copulation and perhaps parturition. In this study, the attachment of two muscles to the pelvic vestiges levator ani and ischium-cavernosus - is confirmed.

The levator ani is attached to the haemal arches and to the ischium of many mammals, including the artiodactyls (Habel, 1975). There is currently a broad consensus that, among the extant groups, artiodactyls are the most commonly cited as the sister group of the Cetacea, and that perhaps they even form a clade (Gingerich et al. 1983; Thewissen et al., 1994; Gatesy, 1997, 1999; O'Leary and Geisler, 1999; Gingerich, 2001, Gatesy and O'Leary, 2001; Thewissen et al. 2001). In cetaceans, this muscle arises in the haemal arches and is inserted to the dorsal margin of the pelvic bone (Lessetisseur, 1968: 692-693), more specifically at the dorsolateral crest and ventromedial protuberance of the cranial process, a name suggested by Duvernoy (after Arvy, 1979).
Kastelein et al. (1997: 138-139) show unequivocally that the muscle involves the pelvic vestiges from the medial face, denominating it pubocaudalis, but recognizing its synonymy with the muscle levator ani.

The ischium-cavernosus muscle arises in the ventrocaudal portion of the pelvic bone, which is usually called "ischial tuberosity", both in cetaceans and in all other mammals (Lessetisseur and Saban, 1967: 851 and 1074; Lessetisseur: 1968: 692, fig. 625; Habel, 1975). Struthers (1893) alone argues that the ischium-cavernosus is directly associated with the "great interpelvic ligament", and not directly to the ischium, but this was not confirmed in the specimens analyzed by us.

Thewissen (2002) and Adam (2002) are the only ones to mention the retractor penis as a muscle directly associated with the pelvic bones, both in modern cetaceans and in the archaeocetes. However, the retractor penis muscle arises in the haemal arches of the first caudal vertebrae in the artiodactyls, without any contact with the pelvic girdle (Habel, 1975). It is probable that both authors have committed an error of synonymy, since the ischiumcavernosus is also known as erector penis (Lessetisseur, 1968:700-701). Here we wish to stress that the retractor penis is not the same muscle than the erector penis (=ischium-cavernosus).

The dorsolateral crest, the ventromedial protuberance and the ischial tuberosity occur, to some degree, in all analyzed species, and their association with the muscles described was verified in P. blainvillei, S. guianensis and T. truncatus, thus constituting homologous structures in

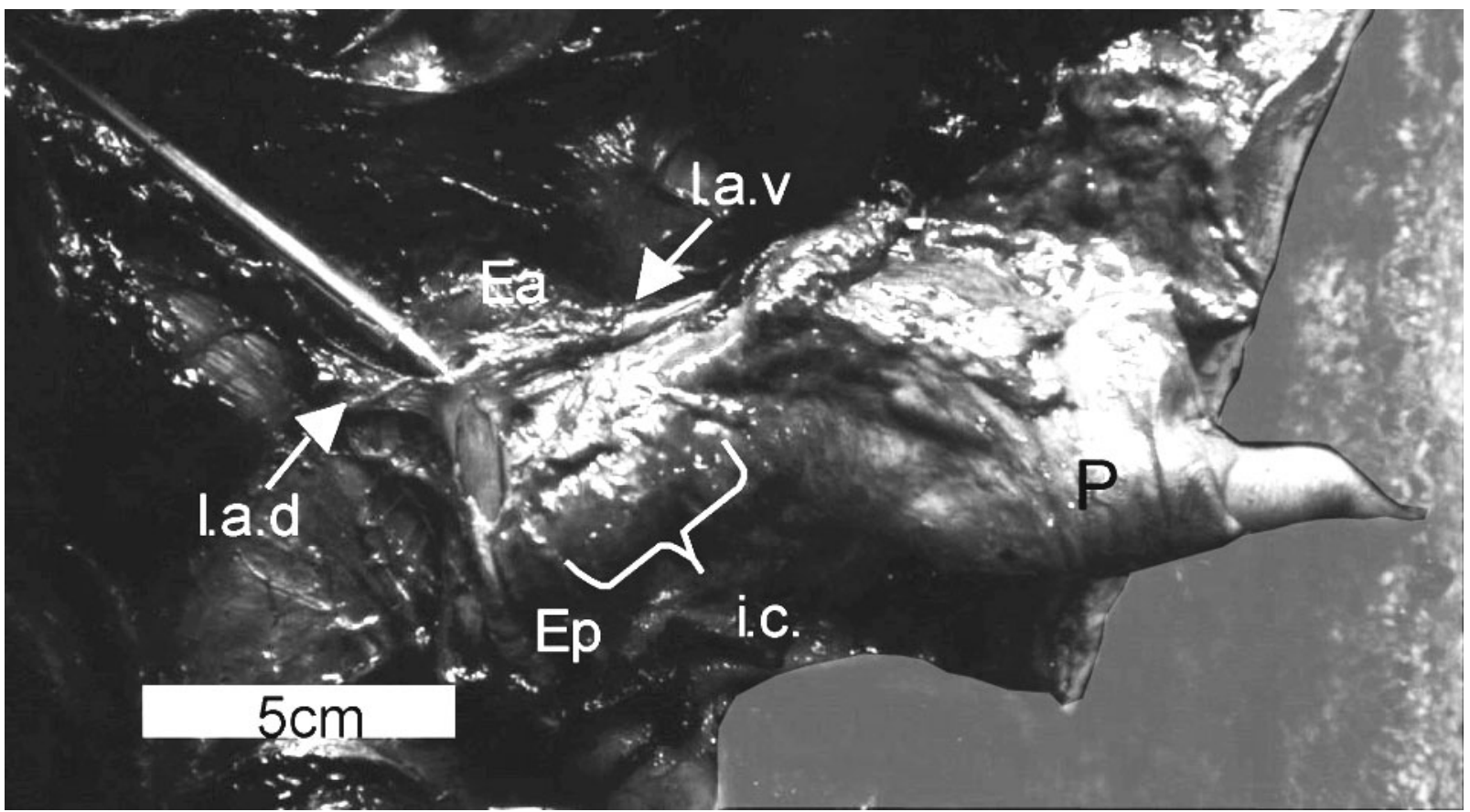

Figure 3. Situation of pelvic bone of the bottlenose dolphin (Tursiops truncatus, UFSC 1295, ventrolateral view), being: 1.a.d) dorsal branch of the levator ani muscle; 1.a.v.) ventral branch of the levator ani; Ea) anterior extremity; and Ep) posterior extremity of the right pelvic bone; P) body of the penis; i.c) ischiumcavernosus. 
all species. Based on this, one can confirm at least the presence of the ischium as a component of the innominate bone of the cetaceans, an opinion that is shared with Howell (1930:305). Nonetheless, there are no signs of the other bones (pubis and ilium) of the pelvic girdle. Such a hypothesis follows the same line adopted by Flower (after Howell, 1930), and Eschricht, Reinhardt and Struthers (after Hosokawa, 1951), who found only one center of ossification in the pelvic bones of fetuses of mysticetes and who also agree with Howell (1930), who analyzed the musculature associated with the pelvic bones and their reduction in the species of archaeocetes.

From such a perspective, the first important reduction of the pelvic girdle occurred in the ilium, due to the loss of the connection with the sacral region of the vertebral column and the reduction of the musculature of the femur, a process that started in the Basilosauridae (Gingerich et al., 1990; 1994; Bejder and Hall, 2002). Hulbert Jr. et al. (1998) mention the loss of terrestrial locomotion in Georgiacethus votglenses also due to the reduction of the ilium. Lessetisseur (1968:643 and 835) considered that the reduction of the cetacean pelvic bones occurred due to the loss of the insertion of abdominal musculature in the pelvis. $\mathrm{He}$ related the reduction of the ilium and of the ischium, regarding the locomotive and visceral girdles, to the activities performed by each of these parts. Their greater development or reduction would be a reflex of the importance of the activities of locomotion or support to the viscera in the differing species.

Only Lönnberg (1938) verified the occurrence of three bones in the pelvic girdle in a specimen of Prodelphinus graffmani (= Stenella atenuatta Gray, 1846), where the sutures were visible. The case described by Lönnberg (1938) should be considered an example of spontaneous atavism, since there are no new records of pelvic bones showing such a separation in the literature. However, it should be mentioned that Cowan (1939) and Omura (1957) suggested that the ilium, ischium and pubis would be fused in one bone, but they did not present any argument to support such a hypothesis.

Lönnberg (1910) also mentioned the attachment of the crura penis in the pelvic girdle of Globicephalus melas (= Globicephala melas Traill, 1809). Since this muscular attachment appears in the ilium of the remaining mammals, its presence would indicate a possible participation of that bone in the composition of the innominate bone of cetaceans. But the attachment of the crura penis was not found in any of the analyzed species in this work, or in the literature, and, most likely, the muscle mentioned by Lönnberg (1910) should be considered as the ischium-cavernosus.

Arvy (1979) claimed that these bones would not have any homology with the pelvic girdle of the remaining mammals, since there is no connection with the vertebral column, nor can they be observed in X-rays of late embryos. His proposition is that there is a homology with the marsupial bones (pre-pubis), considering that they seem to be associated with the perineum. However, the loss of the connection of the pelvic girdle with the sacral region of the vertebral column constitutes the first reduction observed in the archaeocetes (Hulbert Jr. et al., 1998), and their location at a more ventral position is due to the function of supporting the reproductive organs and of defecation (Howell, 1930; Lessetisseur, 1968; Slijper, 1979).

The pelvic bones of the analyzed species are represented by isolated elements, which apparently correspond to the ischium, being that the dorsolateral crest, the ventromedial protuberance, and the ischial tuberosity are homologous in the differing species. The two structures represent distinct attachment areas of the levator ani muscle.

Ruth (1932) reports a center of condensation of scleroblastema being present in each element of the innominate bone of the artiodactyls. Thus, the X-rays of fetuses failed to reveal precocious ossifications, and the cartilaginous pelvis of the P. blainvillei fetus did not allow such visualization. However, according to Hall (1984) and Bejder and Hall (2002), it is due to the late mineralization of the bone, and not to its permanence as cartilage, as suggested earlier by Arvy (1979). In consequence, the homology can only be confirmed by the attachment of the abdominal musculature represented, respectively, by the levator ani and the ischium-cavernosus, which would work in both defecation and in supporting the genital organs.

\section{Acknowledgements}

We are thankful to the referees Mario Cozzuol, and César J. Drehmer and to José Eduardo Dornelles who provided valuable criticism to improve this manuscript. We are also thankful to Fernando S. Vugman, who translated it into English and to Nélio Barros for correcting the grammar in the latter version of the manuscript. P.C. Simões-Lopes received financial support from $\mathrm{CNPq}$ (grant process number 302749/2002-0).

\section{References}

Adam, P.J. (2002) Pelvic Anatomy. Pages 854-897 in Perrin., W.F., Wursig, B. and Thewissen, J.G.M (Eds) Encyclopedia of Marine Mammals. Academic Press, New York.

Andrews, R.C. (1921) A remarkable case of external hind limbs in a humpback whale. American Museum Novitates 9: 1-6.

Arvy, L. (1979) The abdominal bones of cetaceans. Investigations on Cetacea 10: 215-227.

Bejder, L. and Hall, B.K. (2002) Limbs in whales and limblessness in other vertebrates: mechanisms of evolutionary and developmental transformation and loss. Evolution \& Development 4(6): 445-458.

Cowan, I.M. (1939) The Sharp-headed finner whale of the eastern Pacific. Journal of Mammalogy 20(2): 215-225.

Crovetto, A. (1991) Etude ostéométrique et anatomofuncionelle de la colunne vertebrale chez les grands cetaces. Investigation on Cetacea 23: 7-189.

Deimer, P. (1977) Der rudimentare hintere extremitatengurtel des pottwals (Physeter macrocephalus Linnaeus, 1758), seine variabilitat und wachstumsallometrie. Zeitschrift für Säugentierkunde 42: 88-101. 
Gatesy, J. (1997) More DNA support for a Cetacea/ Hippopotamidae clade: the blood-clotting protein gene $Y$ Fibrinogen. Molecular Biology and Evolution 14(5): 537-543.

Gatesy, J. (1999) Stability of cladistic relationships between Cetacea and higher Artiodactyla taxa. Systematic Biology 48(1): 6-20.

Gatesy, J. and O'Leary, M. (2001) Deciphering whale origins with molecules and fossils. Trends in Ecology E Evolution 16(10): 562-570.

Gingerich, P.D. (2001) Origin of whales form early Artiodactyls: hands and feet of Eocene protocetid from Pakistan. Science 293: 2239-2242.

Gingerich, P.D., Wells, N.A., Russell, D.E. and Shah, S.M.I. (1983) Origin of whales in epicontinental remmant seas: new evidences from the early Eocene of Pakistan. Science 220: 403-406

Gingerich, P.D., Smith, B.H. and Simons, E.L. (1990) Hind Limbs of Eocene Basilosaurus: evidence of feet in whales. Science 249: 154-157.

Gingerich, P.D., Raza, S.M., Arif, M. and Anwar, M. (1994) New whale from the Eocene of Pakistan and the origin of cetacean swimming. Nature 368: 844-847.

Habel, R.E. (1975) Pelvic Diafragm. Pages 772-777 in Getty, R. (Ed.) Sisson an Grossman's: the anatomy of domestic animals, W.B.Saunders Company, Philadelphia.

Hall, B.K. (1984) Developmental mechanisms underlying the formation of atavisms. Biological Review of Cambridge Philosophical Society 59: 89-124.

Hosokawa, H. (1951) On the pelvic cartilages of the Baleanoptera-foetuses, with remarks on the specifical and sexual differences. Scientific Report of the Whales Research Institute 5: 5-15.

Howell, A.B. (1930) Aquatic mammals, their adaptation to life in the water. Thomas, Illinois, United States of America.

Hulbert Jr., R.C., Petkewich, R.M., Bishop, G.A., Bukry, D. and Aleshire, D.P. (1998) A new Middle Eocene protocetid whale (Mammalia: Cetacea: Archaeoceti) and associated biota from Georgia. Journal of Paleontology 72(5): 907-927.

Kellogg, R. (1928) The history of whales - their adaptation to life in the water. Quarterly Review of Biology 3: 29-76.

Kastelein, R.A., Dubbeldam, J.L., Luksemburg, J., Stall, C. and van Immerseel, A.A.H. (1997) An anatomical atlas of an adult female harbour porpoise (Phocoena phocoena). Pages 87-178 in Read, A.J., Wiepkema, P.R. and Nachtigall, P.E. (Eds) The Biology of the harbour porpoise. De Spil Publishers, Woerden.

Lessetisseur, J. (1968) Musculature hyposomatique. Pages 549-732 in Grassé, P.-P. (Ed) Traité de Zoologie, Mamifères,
Musculature. Tome 16, Fascicule 2, Masson et Cie editeurs, Paris.

Lessetisseur, J. and Saban, R. (1967) Squelette Appendiculaire. Pages 709-961 in Grassé, P.-P. (Ed) Traité de Zoologie: Anatomie systématique, Biologie. Tome 16, Fascicule 1, Masson et $\mathrm{C}^{\mathrm{ie}}$ editeurs, Paris.

Lönnberg, E. (1910) The pelvic bones of some Cetacea. Arkiv för Zoology 7(10): 1-15.

Lönnberg, E. (1938) Notes on the skeleton of Prodelphinus graffmani Lönnb. Arkiv för Zoology 30A(20): 1-21.

O'Leary, M.A. and Geisler, J.H. (1999) The position of Cetacea within Mammalia: phylogenetic analysis of morphological data from extinct and extant taxa. Systematic Biology 48(3): 455-490.

O'Leary, M.A and Uhen, M.D. (1999) The time of origin of whales and the role behavioral changes in the terrestrial aquatic transition. Paleobiology 25: 534-556.

Omura, H. (1957) Osteological study of the little piked whale from the coast of Japan. Scientific Reports of the Whales Research Institute 12: 1-21.

Omura, H. (1978) Preliminary report on morphological study of pelvic bones of the minke whale from the Antartic. Scientific Reports of the Whales Research Institute 30: 271-279.

Omura, H. (1980) Morphological study of pelvic bones of the minke whale from the Antartic. Scientific Reports of the Whales Research Institute 32: 25-37.

Rommel, S. (1990) Osteology of the bottlenose dolphin. Pages 29-49 in Leatherwood, S. and Reeves, R.R (Eds) The Bottlenose dolphin. Academic press, San Diego.

Ruth, E.B. (1932) A study of the development of the mammalian pelvis. The anatomical record 53(2): 207-225.

Sedmera, D., Misek, I. and Klima, M. (1997) On the development of cetacean extremities: I. Hind limb rudimentation in the spotted dolphin (Stenella attenuata). European Journal of Morphology 35(1): 25-30.

Slijper, E. (1979) Whales. University Press, London, England.

Struthers, J. (1893) On the rudimentary hind-limb of a great fin-whale (Balaenoptera musculus) in comparison with those of the humpback whale and greenland rith-whale. Journal of Anatomy and Physiology 27: 291-335.

Thewissen, J.G.M. (2002) Musculature. Pages 774-778 in Perrin, W., Wursig, B. and Thewissen, J.G.M. (Eds) Encyclopedia of Marine Mammals. Academic Press, New York.

Thewissen, J.G.M., Hussain, S.T. and Arif, M. (1994) Fossil evidence for the origin of aquatic locomotion in archaeocete whales. Science 263: 210-212.

Thewissen, J.G.M., Williams, E.M.; Roe, L.J. and Hussain, S.T. (2001) Skeletons of terrestrial cetaceans and the relationship of whales and artiodactyls. Nature 413: 277-281. 